\title{
Psychosocial Support in Children Victims of Mount Sinabung Eruption
}

\section{Liza Marini", Rahma Yurliani Dalimunthe, Rahmi Putri Rangkuti, Ade Rahmawati Siregar, Debby Anggraini Daulay, Indri Kemala Nasution}

Department of Developmental Psychology, Faculty of Psychology, Universitas Sumatera Utara

\begin{abstract}
The eruption of Mount Sinabung in Tanah Karo, North Sumatera, which occurred in November 2013 has caused some people to evacuate to avoid the risk of greater disaster. The eruption produced psychological impacts not only on the parents but also on the children, due to the disruption of life activities, radical life changes and living with other citizens, in unknown length of time. Based on the situation, the Faculty of Psychology, University of Sumatra Utara as part of the USU's Sinabung Task Force took the initiative to serve the people affected by the Sinabung eruption, especially the children in the form of Psychosocial Support for Children Victims of Sinabung Eruption activities. The activities performed were psychoeducation and psychological assistance. Psychoeducation assistance was provided in the form of training for trainers (TOT) for 15 people from community cadres in Sinabung, while child psychological assistance was done in the form of trauma healing activity in 250 children in evacuation. This services resulted in cadres and children getting their spirits back to focus on the purpose of life they must achieve with their current limitations, more calm, less stress level, more excited, and feel motivated to go back to life with hope for a better future still exist.
\end{abstract}

Keywords: Psychosocial Support, Child Victims of Sinabung Eruption, Training for Trainer, Trauma Healing.

\begin{abstract}
Abstrak. Peristiwa erupsi Gunung Sinabung Kabupaten Tanah Karo Provinsi Sumatera Utara yang terjadi pada bulan November 2013 telah menyebabkan sebagian masyarakat harus mengungsi agar terhindar dari risiko bencana yang lebih besar. Hal ini menimbulkan dampak psikologis bukan saja pada orang tua tetapi juga anak, disebabkan terganggunya aktivitas kehidupan, perubahan hidup yang radikal dan tinggal bersama dengan warga lainnya dalam waktu yang tidak diketahui kapan berakhir. Berdasarkan situasi tersebut maka Fakultas Psikologi Universitas Sumatera Utara sebagai bagian dari Satgas Sinabung USU berinsiatif
\end{abstract} *Corresponding author at: Jl. DR. Mansyur No.7, Padang Bulan, Medan - Indonesia

E-mail address: liza1@usu.ac.id 
melakukan pengabdian kepada masyarakat yang terkena bencana erupsi Gunung Sinabung khususnya kelompok usia anak dalam bentuk kegiatan Psychosocial Support Pada Anak Korban Erupsi Gunung Sinabung. Adapun kegiatan yang dilakukan adalah bantuan psikoedukasi dan psikologis. Bantuan psikoedukasi diberikan dalam bentuk training for trainer (TOT) bagi 15 orang para kader masyarakat di Sinabung, sedangkan bantuan psikologis anak dilakukan berupa kegiatan trauma healing pada 250 anak di pengungsian. Hasil yang didapat dari pengabdian ini adalah para kader dan anak mendapatkan semangat mereka kembali untuk fokus akan tujuan hidup yang harus mereka capai dengan keterbatasan yang dimiliki saat ini, lebih tenang, berkurang tingkat stres nya, lebih gembira, serta merasa mendapatkan motivasi untuk kembali menjalani hidup dengan masih adanya harapan untuk lebih baik ke depannya.

Kata Kunci: Psychosocial Support, Anak Korban Erupsi Sinabung, Training for Trainer, Trauma Healing

Received 6 November 2017 | Revised 1 Febrauary 2019 | Accepted 1 April 2019

\section{Introduction}

Indonesia as a country that has 129 volcanoes that are still active is included in the category of disaster-prone areas. Among the people exposed to the risk of this disaster are those who live around Mount Sinabung, Tanah Karo Regency, North Sumatra Province. Eruption events that occurred in November 2013 have caused some people to evacuate to avoid greater disaster risk. Residents living in the vicinity of the volcano area must be evacuated immediately to reduce casualties. But after a disaster occurs, people affected by the disaster will experience a pattern of life that is different from the previous conditions. Various disasters will have consequences for survivors and will disrupt the functioning of individuals, families and the functioning of a community. Survivors will also lose their jobs as a source of economy, lose their role in society and lose hope for the future [1]. In addition, the impact of the disaster can be in the form of casualties, property, damage of infrastructure, social environment, and disturbances of life and source of income to the people that have been established previously. Losing loved ones, home, property, rice fields, or livestock that is the source of income, it can also cause severe mental shock and trauma [2]. This has psychological impacts not only on parents but also on children, due to disruption of life activities, radical life changes and living with other residents in an unclear time frame.

Various disaster management efforts have been carried out since the beginning of November 2013 until now. In terms of fulfilling the basic needs of disaster survivors, the community has gone well, but psychological assistance especially for children in the 
refugee camps has not been fully facilitated. For children, disasters can be very frightening, their physical body are not as strong as adults, it makes them more vulnerable to disaster threats. Their main sense of security, is the presence of adults around them (parents and teachers) and also the regularity of schedules. Therefore children are also easily affected by the reaction of their parents and other adults. If their parents and teachers react with panic, the child will get more scared. When they live in refugee camps and lose the regularity of their lives. There is no regular schedule for learning and playing activities, making children lose control of their lives [3].

The symptoms of stress experienced by children in post-disaster include: fear of separation from parents or adults, keep on following their parents, fear of strangers, excessive fear of "monsters" or animals, difficulty in sleeping or refusing to go to sleep, compulsive, playing repeatedly as a part of a disaster experiences, returning to previous behaviors, such as bedwetting or thumb sucking, crying easily and screaming, withdrawing, not wanting to play with other children, fear, including nightmares and fears of certain sounds, sights, or objects related to disasters ,problems at school, refusing to go to school and unable to concentrate [3].

The main thing that needs to be done is to be calm when being together with children, because the reaction of adults will affect the child's reaction. Start making regular activities and routines for children. Regular activity is one of the main psychosocial needs for children. Children will feel safe if they immediately carry out activities that are the same / similar to routines or activities carried out before the disaster. Therefore it is very important, to immediately organize an emergency school, find a safe place for children to play in the afternoon, invite children to recite in the afternoon [3].

In one of these activities, encourage children to make pictures about disasters or write stories or poems about disasters. This will help us understand how he or she saw what happened (but also dont forget to do debriefing as a closing). Give the child factual informations about what happened and what will happen in the future. Use simple language, language that can be understood by children. Convince the child that he or she is safe. Children are very vulnerable to feelings of being abandoned when they are separated from parents. Therefore, avoid efforts to "protect" children by sending them to other places but separating them from their loved ones [3].

Based on the situation, the Psychology Faculty of the University of Sumatra Utara has an initiative to provide services to the people affected by the Mount Sinabung eruption, 
especially to the age group of children in the form of Psychosocial Support activities for Children Victims of Mount Sinabung Eruption. The activities will be given in the form of psychoeducation and psychological assistance. Psychoeducation assistance is provided in the form of training for trainers (TOT) for community cadres in Sinabung, so that they are able to do psychosocial assistance directly and independently in the future. While children's psychological assistance is in the form of trauma healing activities that aim to reduce post-eruption stress. Psychosocial Support Activities for Children Victims of Mount Sinabung Eruption will be conducted by the Faculty of Psychology, University of Sumatra Utara as part of the USU Sinabung Task Force in collaboration with the Child Protection Studies Center (CPSC).

\section{Method}

The general objective of conducting Psychosocial Support activities for Children Victims of Mount Sinabung Eruption include:

(1) Empowering cadres in the community through the transfer of knowledge of psychosocial support,

(2) Children can still grow and develop positively even though they are in high risk conditions.

The specific objective of conducting Psychosocial Support activities for Children Victims of Mount Sinabung Eruption include:

(1) Providing activities in the form of knowledge transfer for teachers, students, mosque youth and churche youth. Through the activities, they are expected to be able to provide direct and independent assistance,

(2) Improve the ability to overcome distress through trauma healing activities,

(3) Develop learning skills, cooperation, tolerance and empathy,

(4) Improve social support among refugee children.

As for the target of Psychosocial Support activities for Children Victims of Mount Sinabung Eruption in Training of Trainers (TOT) program are 15 community cadres in Sinabung. The cadres came from 4 evacuation points, KNPI Kabanjahe Building, UKA 1, Fustal Field and Kabanjahe Catholic Church Parish. In addition, psychological assistance was also given to the age group of children living in 1 point of refuge, at the KNPI multi-purpose building in Kabanjahe. The target of child participants are as many as 250 children consisting of children under the age of five and elementary school. 
Psychosocial Support Activities for Children Victims of Mount Sinabung Eruption will be carried out in various forms of activities such as:

1. Training Of Trainers (TOT) Psychosocial Support

The TOT will be held on Tuesday, April 15, 2014. The TOT will be carried out by providing psychoeducation and transfer of knowledge to 15 community cadres consisting of teachers, students, mosque youth and church youth so that later they were able to do psychosocial assistance directly and independently and accordingly to needs while in the relocation area.

In this activity, methods used include:
a. Module presentation,
b. Question \& answer and discussion,
c. Role Play,
d. Games.

\section{Children's Trauma Healing}

Trauma healing will ne carried out on Wednesday, April 23, 2014. This trauma healing will be carried out by giving psychological trauma healing assistance to 250 children in the form of: motor relaxation, free play thematic play, art activity, group healing.

In this activity, methods used include:
a. Games,
b. Relaxation,
c. Art activity,
d. Group support / counseling.

\section{Result and Discussion}

During Psychosocial Support in children victims of Mount Sinabung eruption, has been found several things as follows:

a. The Training of Trainers and children's Trauma Healing activities were facilitated by local volunteers and officers from the Child Protection Studies Center (CPSC) so that it could run smoothly.

b. In some evacuation locations empowerment has been carried out by several community cadres by the Child Protection Studies Center (CPSC) so that they can help their groups when relocating to the village. This community cadres consist of students, teachers, nuns, mosque youth, and church youth. 
c. Psychosocial support was responded positively by the refugee community who obtained services. This can be seen from the request for extension of the activities implementation by the local community, especially community cadres in evacuation.

d. Because there is still a lack of Psychosocial Support activities carried out so that community cadres request that this activity involve more volunteers in all existing evacuation posts.

e. Most of the community cadres and children are still traumatized and have not been able to forget the incident when Mount Sinabung erupted, because at that time they were separated from their parents and family so they did not know what to do.

f. At present, refugees, especially children and adolescents, do not fully know the purpose of their lives in the future, because the conditions that are still unclear and also due to existing economic problems.

g. Most of the refugees are still hesitant to return to their village because they are still afraid that the eruption of Mount Sinabung will happen again because of that, it slows down their healing process in the future.

h. With the participation of the cadres in the Training of Trainers activities, it is enough to encourage them to focus on the goals of life that they must achieve with the limitations they possess now.

i. The Training of Trainer cadre participants liked the method that was carried out in delivering the material as to make them cheerful, re-energized and add insights into the handling of trauma in children.

j. Due to the lack of time available, the schedule of children who have to go to school made Trauma Healing activities for children that was carried out through drawing and storytelling couldn't be done maximally to all children.

The data obtained shows that most of the community cadres and children are still traumatized and have not been able to forget the incident when Mount Sinabung erupted, therefore devotion is made in the form of psychosocial support (psychosocial support). Psychosocial support is an assistance provided to individuals and communities who experience psychological disorders, where this assistance is carried out continuously and giving influenced between psychological aspects and social aspects in an environment where individuals or communities are located [4]. Psychological support aims to restore individuals, families, communities so that after a disaster occurs, they will be stronger 
together, function optimally and have the strength to face problems so that they become productive and effective [4].

In accompanying survivors, humanitarian workers engaged in the psychosocial field should have the basic skills needed to assist them. For example, the skills to listen and soothe or relieve explosive emotions, provide emotional first aid skills, and others [4]. Therefore some intervention techniques have been done in this devotion activity, as shown in Table 1.

Table 1. Some intervention technique in physicosocial support for child victims of Sinabung eruption
1. Psychological First Aid
A calming technique, defusing and debriefing, overcoming panic.
2. Adult Relaxation Visualization: a comfortable place, breathing: regulate the breath.
3. Child Relaxation Visualization: a comfortable place, breathing:
4. Recretional Activity regulate the breath.
5. Expressive Therapy
Storytelling, traditional games.
Drawing and Storytelling.

After participating in this series of psychosocial support activities, cadre participants felt more calm, reduced their sense of stress, and added insights into the handling of trauma in children. Likewise for survivors of children who participated as participants in this activity, where they became more cheerful, enthusiastic, and felt motivated to return to live with the hope of being better in the future.

\section{Conclusion}

From the implementation of Psychosocial Support in children victims of Mount Sinabung eruption ,the conclusion are as follows:

a. In general, the Training of Trainers and Trauma Healing activities for children have been able to run smoothly and well, due to the facilitation from various parties, namely the University of Sumatra Utara, the Psychology Faculty of USU, local officials at the evacuation posts and officers from the Child Protection Studies Center (CPSC).

b. Testimony from refugee communities after obtaining psychosocial services states that they feel calmer, less stressed, happier, happy to see their children excited, and feel motivated to return to the life fill with hope for a better future. Especially the support of the current economic recovery is the most urgent immediate assistance. 
In order for psychosocial activities to run smoothly as expected, preparation is necessary, especially for trained volunteers who are ready to work in sufficient time as needed in the field. Debriefing, monitoring, and evaluation of the abilities and skills of volunteers need to be done continuously.

\section{References}

[1] Hackbarth, M., Pavkov, T., Wetchler, J., Flannery, M. 2012. Natural Disaster, An Assessment of Family Resiliency Following Hurricane.

[2] Hikmawaty, E., and Rusmiyati, C. 2012. Penanganan Dampak Sosial Psikologis Korban Bencana Merapi : Jurnal Informasi, 17(2), 97-110.

[3] Kharismawan, K. 2010. Buku Panduan Program Psikososial Pasca Bencana. Jakarta: Unika Soegijapranta.

[4] Kodir, M. 2016. Dukungan Psikososial Pasca Bencana. Retrieved from http://dinsos.jatengprov.go.id/dukungan-psikososial-pasca-bencana.html Accessed on : 23 October 2017. 